Volume 3 Issue 1, March 2019: pp. 50-66. Copyright (c) 2019 HOLREV. Faculty of Law, Halu Oleo University, Kendari, Southeast Sulawesi, Indonesia. ISSN: 2548-1762 | e-ISSN: 2548-1754. Open Access at: http://ojs.uho.ac.id/index.php/holrev/

\title{
Ketentuan-ketentuan TRIPS-Plus dalam Kerangka Perjanjian Perdagangan Bebas
}

\section{TRIPS-Plus Provisions Under a Frame of Bilateral Free Trade Agreement}

\author{
Safril Sofwan Sanib \\ Dosen Fakultas Hukum Universitas Halu Oleo \\ E-mail: safrilsanib@yahoo.co.id
}

\begin{abstract}
The objective of this research is to analyze and find the philosophy of TRIPS-Plus Provisions under the framework of Bilateral Free Trade Agreements (BFTA). This research is legal research by using a statutory, conceptual and comparative approach. This research found that the philosophy of the provisions of TRIPS-Plus under BFTA is to eliminate the minimum standards and flexibility contained in the provisions of TRIPS Agreement of the WTO which have impacts on: (1) restricting the grounds for exclusion of patentability; (2) limitations on the issuing of compulsory licences; (3) limiting the scope of exhaustion of rights; (4) extension of patent providing term; (5) patent-like protection for plant varieties; (6) exclusivity over test data with respect to pharmaceutical and chemical products; (7) protection for new types of trade mark; and (8) strong protection for digital technologies. If countries agree on BFTA with partners / trading partners about IPR provisions containing TRIPS-Plus above, it will cause the country to not be able to use the flexibilities provided by IPR agreements at the multilateral level (TRIPS Agreement) and this will affect fulfillment of basic rights such as: the right to education, the right to health and access to affordable and inexpensive medicines, and the right to food.
\end{abstract}

Keyword: TRIPS-Plus; bilateral; protection

Abstrak: Tujuan dari penelitian ini adalah untuk menganalisis dan menemukan filosofi Ketentuan TRIPS-Plus di bawah kerangka Perjanjian Perdagangan Bebas Bilateral (Bilateral Free Trade Agreements=BFTA). Penelitian ini adalah penelitian hukum dengan menggunakan pendekatan perundang-undangan, konseptual, dan komparatif. Penelitian ini menemukan, bahwa filosofi dari ketentuan TRIPS-Plus di bawah BFTA adalah untuk menghilangkan standar minimum dan fleksibilitas yang terkandung dalam ketentuan Perjanjian TRIPS WTO yang berdampak pada: (1) pembatasan alasan untuk pengecualian dari invensi yang bisa di patenkan; (2) membatasi penerbitan lisensi wajib; (3) pembatasan ruang lingkup exhaustion of rights dan impor paralel; (4) perpanjangan jangka waktu pemberian paten; (5) 
kewajiban perlindungan paten untuk perlindungan varietas tanaman; (6) eksklusivitas atas uji data berkenaan dengan produk farmasi dan kimia; (7) perlindungan untuk jenis-jenis merek dagang baru (8) perlindungan yang kuat untuk teknologi digital. Bila negara-negara menyepakati BFTA dengan mitra/partner dagang tentang ketentuan-ketentuan HKI yang mengandung TRIPSPlus tersebut di atas maka akan menyebabkan negara tersebut tidak dapat menggunakan fleksibilitas yang diberikan oleh perjanjian HKI pada level multilateral (TRIPS Agreement) dan hal tersebut berdampak pada tidak terpenuhinya hak-hak dasar yaitu: hak atas pendidikan, hak atas kesehatan dan akses obat-obatan secara terjangkau dan murah, serta hak atas pangan.

Kata kunci: TRIPS-Plus; bilateral; perlindungan

\section{PENDAHULUAN}

Pengertian Hak Kekayaan Intelektual (selanjutnya disebut HKI) adalah: the rights given to persons over the creations of their minds. They usually give the creator an exclusive right over the use of his/her creation for a certain period of time. ${ }^{1}$ Pada level internasional HKI diatur dalam perjanjian Trade Related Aspects on Intellectual Property Rights (selanjutnya disebut TRIPS). Perjanjian TRIPS ini merupakan standar perlindungan HKI pada level internasional yang telah disepakati oleh negara-negara sebagai bagian dari kesepakatan perdagangan multilateral dalam kerangka pembentukan World Trade Organization (selanjutnya disebut WTO). Meskipun demikian, diskursus mengenai perjanjian TRIPS dari berbagai perspektif masih terus berlangsung. Nurul Barizah ${ }^{2}$ mendeskripsikan TRIPS sebagai berikut:

"The TRIPS Agreement is a pivotal legal document dealing with Intellectual Property Rights. This Agreement is the most significant, influential, and comprehensive agreement on Intellectual Property Rights as one of the pillars of the WTO global trade regime. It deals with listed ranges of Intellectual Property Rights, establishing minimum universal standards of protection, requiring effective enforcement measures and establishing a dispute settlement mechanism. Due to its significant outreach, scholars describe this agreement as involving a radical change, a 'conceptual leap', in the history of Intellectual Property Rights, including revolutionising international Intellectual Property Laws".

Artinya, perjanjian TRIPS merupakan dokumen hukum yang sangat penting, yang paling berpengaruh dan paling komprehensif sebagai salah satu pilar dari rezim perdagangan WTO. Perjanjian TRIPS adalah perjanjian yang menetapkan standar

1 World Trade Organization, What Are Intellectual Property Rights?, World Trade Organization, https://www.wto.org/english/tratop_e/TRIPS_e/TRIPS_e.htm \#WhatAre. diakses pada tanggal 28 Agustus 2017.

2 Nurul Barizah, Intellectual Property Implications on Biological Resources: Indonesia's Adoption of International Intellectual Property Regimes and the Failure to Adequately Address the Policy Challenges In the Area of Biological Resources, Jakarta: The Nagara Institute, 2010, hlm. 54-55. 
minimum dan fleksibilitas dalam perlindungan HKI serta mewajibkan setiap anggota untuk menerapkannya dalam peraturan perundang-undangan nasionalnya. ${ }^{3}$ Namun, pasca penandatanganan perjanjian TRIPS muncul keinginan negara-negara maju disponsori oleh Amerika Serikat dan negara-negara Eropa untuk mengubah standar perjanjian TRIPS dari yang minimum ke standar yang maksimum dan sering disebut dengan TRIPS-Plus melalui Bilateral Free Trade Agreement (BFTA) atau Perjanjian Perdagangan Bebas Bilateral.

Berdasarkan kondisi di atas Perjanjian BFTA TRIPS-plus ini mendapatkan banyak resistensi dari negara-negara berkembang seperti Brazil dan Argentina dengan alasan bahwa perjanjian tersebut akan mematikan potensi negara-negara berkembang dan yang masih sedang akan berkembang. ${ }^{4}$ Pada prinsipnya, TRIPS-Plus telah melampaui ketentuan yang sudah ada dalam Perjanjian TRIPS. Perjanjian karena: (1). Pengaturan area baru HKI (perlindungan non original database); (2). Penerapan standar yang lebih luas (memperpanjang jangka waktu perlindungan merek dagang dari 10-15 tahun, sedangkan hak cipta, perhitungan perlindungan selama seumur hidup pencipta sampai setelah pencipta meninggal dunia ditambah 75-95 tahun); dan (3). Penghapusan pilihan untuk anggota di bawah Kesepakatan TRIPS (kewajiban untuk melindungi varietas tanaman "Hanya" the International Union for the Protection of New Varieties of Plants (UPOV) system 1991). ${ }^{5}$ Berdasarkan isu hukum yang dijelaskan dalam latar belakang di atas, maka yang menjadi rumusan masalahnya adalah apa landasan filosofis dari adanya ketentuan TRIPSPlus dalam Perjanjian Perdagangan Bebas Bilateral?

3 Achmad Zen Umar Purba Perjanjian TRIPS dan Beberapa Isu Strategis, Badan Penerbit F.H Universitas Indonesia dan Jakarta-Bandung: P.T. Alumni, 2011, hlm. 171.

4 R. Mayne, Regionalism, Bilateralism, and "TRIPS-Plus" Agreements: The Threat to Developing Countries. UNDP Human Development Report Office Occasional Paper, 2005, hlm. 5.

5 David Vivas-Eugui, Regional and bilateral agreements and a TRIPS-Plus world: the Free Trade Area of the Americas (FTAA), Geneva and Ottawa: Quaker United Nations Office (QUNO), Quaker International Affairs Programme (QIAP), International Centre for Trade and Sustainable Development (ICTSD), 2003 , hlm. 4. Lihat juga: Bryan Mercurio, "TRIPS-Plus Provisions in FTAs: Recent Trends", http://papers.ssrn.com/abstract_id=947767 hlm. 219, diakses pada tanggal 20 Agustus 2016, Begitu juga pendapat Graham Dutfield, menyatakan ketentuan-ketentuan TRIPS-Plus terdiri; memperpanjang paten dan hak cipta untuk jenis materi yang baru; menghilangkan atau mempersempit pengecualian yang diizinkan termasuk yang masih disediakan dalam hukum HKI Amerika Serikat dan Eropa; memperpanjang persyaratan perlindungan; memperkenalkan aturan HKI baru yang dimandatkan TRIPS lebih awal dari periode transisi yang diizinkan oleh TRIPS; dan meratifikasi perjanjian WIPO baru yang berisi langkah-langkah TRIPS-Plus. Graham Dutfield "To Copy Is To Steal": Trips, (Un)Free Trade Agreements and The New Intellectual Property Fundamentalism', 2006 (1) The Journal of Information and Technology Law (JILT), http://go.warwick.ac.uk/jilt/2006_1/dutfield/, hlm. 5. diakses pada tanggal 26 Juli 2016. 


\section{METODE PENELITIAN}

\section{Tipe Penelitian}

Penelitian tersebut mengacu pada penelitian hukum (legal research). Karakteristik penelitian hukum yakni mencari kebenaran koherensi yang mana suatu kebenaran didasarkan pada kesesuaian antara yang ditelaah dengan aturan yang ditetapkan. Menurut Peter Mahmud Marzuki, bahwa penelitian hukum adalah suatu proses untuk menemukan aturan hukum, prinsip-prinsip hukum, dan doktrin-doktrin hukum guna menjawab isu hukum yang dihadapi. Hal tersebut sesuai dengan karakter preskriptif dari ilmu hukum6.

\section{Pendekatan Masalah}

Prinsip-prinsip perlindungan HKI yang diimplementasikan dalam Hukum HKI Nasional dalam kerangka perjanjian perdagangan bebas bilateral merupakan penelitian hukum yaitu suatu proses untuk menemukan aturan hukum, prinsip-prinsip hukum maupun doktrin hukum guna menjawab isu hukum yang dihadapi. ${ }^{7}$ Hasil yang dicapai adalah untuk memberikan preskripsi mengenai apa yang seyogyanya atas isu hukum. ${ }^{8}$ Adapun pendekatan digunakan dalam penelitian ini adalah:

a. Pendekatan Undang-undang (statute approach)

Pendekatan ini dilakukan dengan menelaah semua undang-undang dan regulasi yang bersangkutan dengan isu hukum, ${ }^{9}$ yaitu ketentuan-ketentuan TRIPS dan TRIPS-Plus yang mengatur tentang HKI dan konvensi-konvensi internasional lain yang relevan. Pendekatan ini bertujuan mempelajari ratio legis dan dasar ontologis suatu ketentuan-ketentuan tersebut guna mendapatkan kandungan filosofis yang ada di belakang ketentuan-ketentuan tersebut terutama ketentuan TRIPS-Plus.

b. Pendekatan Konseptual (Conceptual Approach)

Pendekatan ini beranjak dari pandangan-pandangan dan doktrin-doktrin yang berkembang dalam ilmu hukum, kemudian menemukan ide-ide yang melahirkan pengertian-pengertian hukum, konsep-konsep hukum, dan asas-

Peter Mahmud Marzuki, Penelitian Hukum, Jakarta: Kencana Prenada Media Group, 2010, hlm. 77.

Ibid., hlm. 35.

Ibid., hlm. 41.

Ibid., hlm. 93. 
asas hukum yang relevan dengan isu yang di hadapi. ${ }^{10}$ Serta, mempelajari pandangan-pandangan dan doktrin-doktrin tentang HKI, TRIPS dan prinsipprinsip TRIPS-Plus. Pendekatan penelitian ini untuk mengungkapkan ide-ide yang melahirkan pengertian-pengertian hukum, konsep-konsep hukum, dan asas-asas hukum yang berkaitan dengan perlindungan HKI terutama TRIPSPlus.

c. Pendekatan Komparatif

Pendekatan perbandingan dilakukan dengan mengadakan studi perbandingan hukum. Pendekatan ini membandingkan antara ketentuan-ketentuan HKI yang ada dalam TRIPS WTO, dengan ketentuan-ketentuan HKI yang ada dalam BFTA yang dilakukan oleh negara maju dan negara berkembang. Selanjutnya, mengungkapkan kelebihan dan kekurangan masing-masing ketentuan tersebut.

\section{ANALISIS DAN PEMBAHASAN \\ Filosofi Ketentuan TRIPS-Plus Dalam Perjanjian Perdagangan Bebas Bilateral Pengertian TRIPS-Plus}

Pada dasarnya Perjanjian TRIPS hanya menetapkan standar minimum perlindungan HKI. Artikel 1.1 TRIPS dengan tegas memberikan kebebasan setiap anggota WTO untuk pelaksanaan perlindungan HKI. Ketentuan ini adalah suatu pilihan, bukan suatu kewajiban seperti di dalam perjanjian FTA. Menurut Sunil Kumar Agarwa11:

"The principle of minimum intellectual property standards is the cornerstone of the TRIPS Agreement. The principle constitutes a significant conceptual and strategic basis for subsequent multilateral and bilateral intellectual property negotiations aimed at setting higher standards. Its effect is that any intellectual property agreement negotiated subsequent to TRIPS among and/or involving WTO members can only create higher standards. Higher standards, which could result from bilateral, plurilateral or multilateral treaties, have come to be commonly referred to as TRIPSplus".

Berdasarkan pernyataan di atas, bahwa TRIPS menetapkan prinsip standar minimum HKI yang menjadi landasan perjanjian TRIPS. Prinsip tersebut merupakan konsep signifikan dan dasar strategi untuk kelanjutan negosiasi HKI multilateral dan

10 Ibid., hlm. 95

11 Sunil Kumar Agarwa, TRIPS-plus Agenda Through Anti-counterfeiting Trade Agreement: Implication For India, Social Science Research Network, tersedia di SSRN: http://ssrn.com/abstract=1868026 or http://dx.doi.org/10.2139/ssrn.1868026, hlm. 2, diakses pada tanggal 21 September 2017. 
bilateral yang bertujuan untuk menetapkan standar yang lebih tinggi. Efeknya, bahwa setiap perjanjian HKI yang dinegosiasikan setelah TRIPS antara dan/atau melibatkan anggota WTO, hanya bisa membuat standar yang lebih tinggi. Kenyataan sekarang ini standar yang lebih tinggi, merupakan hasil dari perjanjian bilateral, multilateral atau plurilateral, yang sering disebut dengan TRIPS-Plus.

Pengertian TRIPS-Plus Standard adalah perlindungan HKI dengan standar yang lebih tinggi dari standar yang ditetapkan perjanjian TRIPS. ${ }^{12}$ David Vivas-Eugius ${ }^{13}$ menyatakan, perjanjian TRIPS adalah salah satu perjanjian kunci dalam WTO, sudah membebankan standar minimum yang relatif tinggi, untuk HKI pada semua anggota WTO. Kemudian, Sisule F Musungu and Graham Dutfield, TRIPS-Plus adalah sebuah konsep yang mengacu pada penerapan peraturan dan praktik HKI multilateral, plurilateral, regional dan/atau nasional yang mempunyai efek mengurangi kemampuan negara-negara berkembang untuk melindungi kepentingan publik. ${ }^{14}$ Keduanya berpendapat bahwa TRIPS-Plus termasuk setiap standar baru yang akan membatasi negara-negara untuk: ${ }^{15}$ (1). mempromosikan inovasi teknologi dan untuk memfasilitasi transfer dan penyebaran teknologi; (2). melakukan tindakan yang diperlukan untuk melindungi kesehatan masyarakat, gizi dan untuk mempromosikan kepentingan publik di sektor sosial-ekonomi dan teknologi; atau, (3). melakukan tindakan yang tepat untuk mencegah penyalahgunaan HKI oleh pemegang hak atau yang dikuasakan oleh pemegang hak untuk praktik-praktik yang tidak wajar yang menghambat perdagangan atau mempengaruhi transfer teknologi internasional.

\section{Ketentuan-ketentuan TRIPS-Plus}

TRIPS-Plus komitmen tidak hanya terjadi di negosiasi bilateral dan regional, tetapi juga di forum internasional di luar WTO seperti WIPO. Ada keprihatinan atas komitmen TRIPSPlus, karena negosiasi pada berbagai tingkat ini mempromosikan "satu ukuran cocok untuk semua."16 Ada risiko, bahwa perjanjian regional dan bilateral dapat mengganggu

\footnotetext{
12 Nurul Barizah, "TRIP-Plus Provisions on Patent Under Indonesia's Bilateral Free Trade Agreement", Jurnal Hukum Ius Quia Iustum No. 3 Vol. 21 Juli 2014: 356 - 377, hlm. 1.

13 David Vivas-Eugui 2003., Op.Cit., hlm. 4.

14 Sisule F Musungu and Graham Dutfield, Multilateral Agreements and a TRIPS-Plus World: The World Intellectual Property Organisation (WIPO), Geneva and Ottawa: Quaker United Nations Office (QUNO), Quaker International Affairs Programme (QIAP), 2003, hlm. 3.

15 Sisule F Musungu and Graham Dutfield, Ibid, hlm. 4.

16 David Vivas-Eugui, Op.Cit. hlm. 4.
} 
sistem multilateral yang pada umumnya membatasi penggunaan fleksibilitas dan pengecualian oleh negara-negara berkembang yang diizinkan dalam kesepakatan TRIPS. Menurut Kinda Mohamadieh (dkk), ${ }^{17}$ kewajiban TRIPS-Plus yang ditetapkan melalui FTA bilateral, terutama dengan Amerika Serikat, berwujud dalam bentuk eksklusivitas data, perpanjangan aturan paten, pembatasan penggunaan lisensi wajib, pembatasan ruang lingkup exhaustion of rights dan impor paralel, perlindungan data, dan mengaitkan paten dengan persetujuan pemasaran obat.

\section{Perlindungan Paten}

Pemegang paten dapat mengamankan monopolisasi dan menghindari persaingan, ketentuan BFTA pada HKI umumnya berfokus pada:

a. Pembatasan Alasan untuk Pengecualian Paten

Kebanyakan BFTA Amerika Serikat (disingkat AS) mempertahankan prinsipnya, bahwa perlindungan yang efektif dan memadai harus diberikan kepada penemuan di segala bidang teknologi. Produk-produk tersebut saat ini dikecualikan dari perlindungan paten, seperti tanaman, hewan, proses biologis yang esensial dan produk, gen, rentetan gen, metode bisnis dan program komputer, harus dilindungi oleh hukum hak paten dari negara penandatanganan kesepakatan BFTA.

Selanjutnya, berkaitan dengan pematenan bentuk kehidupan. Prinsip hukum paten yang berlaku umum, bahwa bentuk kehidupan tidak dapat dipatenkan. Ruang lingkup paten telah diperluas untuk mencakup bentuk kehidupan dan kehidupan organisme seperti mikro-organisme. Kemajuan dalam penemuan bioteknologi, inovasi, dan aplikasinya telah menantang teori paten, menimbulkan pertanyaan tentang bagaimana teknologi tersebut dapat dipatenkan dan bagaimana caranya memenuhi batas perlindungan paten khusus secara kolektif. ${ }^{18}$ Sehingga, dalam perjanjian TRIPS meletakkan dasar untuk perlindungan bentuk kehidupan, meskipun secara teoritis, hal tersebut bisa disanggah karena bentuk kehidupan tidak termasuk dalam kategori "penemuan" berdasarkan Pasal 27.1 TRIPS. Calvalho berpendapat, paten

17 Kinda Mohamadieh et.al, The Arab Region and Trade Liberalization Policies A Look Into Sectoral Implications, Beirut, Lebanon: The Arab NGO Network For Development (ANND), hlm. 72.

18 lihat Carlos M Correa, Integrating Public Health Concern into Patent Legislation in Developing Countries, Geneva: South Centre, 2000, hlm. 99. 
adalah teknologi yang netral, ${ }^{19}$ harus diberikan kepada semua jenis teknologi tanpa diskriminasi. ${ }^{20}$ Berdasarkan United States-BFTA, AS cenderung menekankan prinsip tersebut. ${ }^{21}$ Artinya, semua kategori bentuk kehidupan dapat dipatenkan, termasuk gen dan rentetan gen. Saat ini paten tidak diberikan untuk organisme hidup, ${ }^{22}$ algoritma matematika dan kode objek.

b. Keterbatasan pada Penerbitan Lisensi Wajib

Filosofi dasar paten, bahwa hak monopoli harus disediakan untuk memfasilitasi peningkatan akses ke teknologi baru dan know-how. Hak eksklusif tidak boleh digunakan sebagai penghambat perlindungan hak konsumen untuk produk penting. Lisensi wajib ${ }^{23}$ merupakan mekanisme untuk pemilik paten untuk bertindak sesuai ketentuan ini.

Pada prinsipnya, lisensi wajib diberikan atas dasar non-sukarela. Berdasarkan Perjanjian TRIPS dan Konvensi Paris, negara-negara diperbolehkan untuk menggunakan lisensi wajib paten, asalkan kondisi tertentu terpenuhi. ${ }^{24}$ Maka, dalam ketentuan TRIPS-Plus berdasarkan BFTA AS juga berupaya untuk membatasi tindakan penting seperti lisensi wajib pada situasi tertentu dan membuat prosedur untuk mengeluarkan lisensi wajib yang rumit dan berkepanjangan. ${ }^{25}$ Selain itu, ekspor obat berlisensi wajib ke negara-negara yang tidak memiliki atau tidak cukup kapasitas produksi tidak akan dapat

19 Carvalho, Nuno Pires de, The TRIPS Regime of Patent Right, 2nd Edition, The Netherlands: Kluwer Law International, 2005, hlm. 9.

20 Pasal 27 dari TRIPS Agreement.

21 Pasal 16.7.1 dari United State-Singapore BFTA, United States Trade Representative, https://ustr.gov/trade-agreements/free-trade-agreements/singapore-fta/final-text. Dikunjungi pada tanggal 20 Oktober 2017.

22 Grup Afrika, telah secara konsisten menyuarakan keprihatinan tentang implikasi ketentuan perjanjian tentang bentuk kehidupan. Dalam pandangan mereka, paten tidak boleh diberikan pada mikroorganisme, proses non-biologis dan mikrobiologi untuk produksi tanaman dan hewan. Karena hal tersebut "bertentangan dengan struktur masyarakat dan budaya mereka, dan memohon pengecualian dalam hal tersebut. Lihat Note by the WTO Secretariat. The relationship between the TRIPS Agreement and the Convention on Biological Diversity: Summary of issues raised and points made', IP/C/W/369/Rev.1, 9 March 2006, Paragraphs 28-29.

23 Lisensi wajib memungkinkan negara yang memegangnya untuk memproduksi atau mengimpor bentuk generik dari produk yang dipatenkan. Berdasarkan Deklarasi Doha tentang Perjanjian TRIPS dan Kesehatan Masyarakat (Diadopsi pada 14 November 2001), setiap Anggota memiliki hak untuk memberikan lisensi wajib dan kebebasan untuk menentukan dasar yang menjadi dasar pemberian lisensi tersebut. Kinda Mohamadieh dkk, Op.Cit., hlm. 72

24 TRIPS Pasal 31, Paris Convention, Pasal. 5A.

25 Jakkrit Kuanpoth, TRIPS-Plus Rules under Free Trade Agreements: An Asian Perspective, dalam Christopher Heath and Anselm Kamperman Sanders (ed), Intellectual Property and Free Trade Agreements, Oregon: Oxford and Portland, 2007, hlm. 34. 
dilaksanakan. ${ }^{26}$ Lisensi wajib adalah fleksibilitas penting yang terkandung dalam Pasal 31 TRIPS untuk memungkinkan produsen obat generik menggunakan paten guna memproduksi obat-obatan dengan biaya yang lebih rendah dan mekanisme ini dianggap sebagai cara untuk mengatasi masalah akses pada obat-obatan dan kesehatan masyarakat pada anggota WTO. ${ }^{27}$ BFTA AS, melarang mitra dagang untuk mencabut paten. Lisensi wajib menjadi satu mekanisme yang dapat digunakan untuk mengurangi praktik-praktik kasar dari pemegang hak. ${ }^{28}$ Sejak TRIPS-Plus menetapkan ruang lingkup, durasi dan cakupan ketentuan lisensi wajib, negara-negara yang sedang berkembang akan memiliki sedikit ruang untuk melakukan penyesuaian dalam hukum nasionalnya untuk memenuhi kebutuhan khusus mereka. ${ }^{29}$

c. Membatasi ruang lingkup exhaustion of rights dan Impor Paralel

Doktrin exhaustion membahas masalah kapan pemegang HKI mengontrol atas distribusi obat berhenti. Ide dasarnya adalah ketika pemegang hak telah memperoleh pengembalian ekonomi dari penjualan pertama atau menempatkan obat di pasar, pembeli atau penerima obat berhak untuk menggunakan dan menyebarkannya tanpa pembatasan lebih lanjut. ${ }^{30}$ Selain itu juga, usulan AS untuk rancangan FTA bertujuan memperkuat HKI melampaui apa yang diperlukan dalam TRIPS dengan melarang adopsi dari doktrin "exhaustion of rights", yaitu penjualan pertama dari suatu objek perwujudan suatu HKI di negara asing penerima hak eksklusif pemegang hak itu. ${ }^{31}$

d. Perpanjangan Jangka Waktu Paten

26 Ibid.

27 Ping Xiong, "TRIPS-Plus Provisions And The Approaches To Interpretation Of Free Trade Agreements And TRIPS: Do They Affect Public Health?", Journal of World Trade, Vol. 46, No. 1, 2012, hlm. 174.

28 Jakkrit Kuanpoth, Op.Cit., hlm. 6.

29 Ibid.

30 Pedro Roffe, Christoph Spennemann and Johanna von Braun, Intellectual property rights in free trade agreements: moving beyond TRIPS minimum standards dalam Research Handbook on the Protection of Intellectual Property under WTO Rules Intellectual Property in the WTO Volume I, edited by Carlos M. Correa, Cheltenham, UK: Edward Elgar, 2010, hlm. 296.

31 Menurut Pasal 6 TRIPS, negara-negara dapat menerapkan the exhaustion principle secara berbeda. Beberapa mungkin menerapkan prinsip ketika obat dijual di perbatasan nasional saja (disebut National exhaustion), tetapi negara-negara lain, terutama Uni Eropa, tidak mengizinkan pembatasan impor ketika obat dijual pada anggota masyarakat (disebut regional exhausting). Berdasarkan prinsip ketentuan paten, hak paten habis setelah pemasaran pertama oleh pemegang hak atau dengan persetujuannya, terlepas dari tempat pemasaran. Jakkrit Kuanpoth, Op.Cit., catatan kaki nomor 4. 
Jangka waktu perlindungan paten berdasarkan Perjanjian TRIPS adalah dua puluh (20) tahun. Jangka waktu ini adalah sesuatu yang layak untuk menghargai perlindungan penemu atas upaya inovatif. Beberapa produk, seperti obat-obatan dan bahan kimia pertanian, memerlukan otorisasi resmi sebelum produk tersebut dipasarkan. ${ }^{32}$ Penandatanganan FTA juga diperlukan untuk memperpanjang jangka waktu perlindungan paten dalam kasus penundaan yang tidak rasional dalam pemberian paten. ${ }^{33}$

e. Paten untuk Perlindungan Varietas Tanaman

Pasal 27.3 (b) dari TRIPS memberikan pilihan negara-negara penandatanganan untuk memberikan perlindungan varietas tanaman dengan hak paten atau dengan sistem sui generis yang efektif atau juga dengan keduanya. Biasanya dipilih bukan perlindungan paten karena banyak negara telah melindungi varietas tanaman di bawah Plant Breeders' Rights (PRBs) of the UPOV Convention. ${ }^{34}$ Perlindungan paten untuk varietas tanaman dianggap kurang tepat bagi negara-negara yang sedang berkembang karena persyaratan kebaruan, langkah inventif, aplikasi industri dan pengungkapan secara tertulis yang cukup. ${ }^{35}$

Terkait dengan konsep hak-hak petani yang diadopsi oleh Organisasi Pangan dan Pertanian (FAO) memiliki tujuan untuk memberikan penghargaan kepada petani yang telah melestarikan sumber daya genetik tanaman dan telah memberi kontribusi pada pengembangan varietas tanaman. Persyaratan hukum, seperti pemberian prior informed consent ${ }^{36}$ dan pembagian keuntungan

32 Yi-Jen Chu, The Evolution of US and EU Approaches to Intellectual Property Provisions Related to Public Health in Free Trade Agreements: Are They Responding to Public Health Concerns?, Munich Intellectual Property Law Center (MIPLC) Master Thesis (09/10) No. 5, hlm. 26.

33 Ketentuan yang dinegosiasikan oleh Amerika Serikat mencerminkan hukum domestik Amerika dan berasal dari US Drug Price Competition and Patent Term Restoration Act of 1984 (Hatch-Waxman Act) sebagaimana dikutip oleh Bryan Mercurio, Op.Cit., hlm. 229.

34 David Vivas-Eugui, Op.Cit, hlm. 19.

35 Pedro Roffe, Bilateral agreements and a TRIPS-Plus World: the Chile-USA Free Trade Agreement, Quaker International Affairs Programme, Ottawa, 2004. hlm. 20.

36 Free, Prior and Informed Consent (FPIC) adalah prinsip yang dilindungi oleh standar hak asasi manusia internasional yang menyatakan, 'semua orang memiliki hak untuk menentukan nasib sendiri' dan terkait dengan hak untuk menentukan nasib sendiri - 'semua orang memiliki hak untuk bebas mengejar ekonomi, sosial dan pengembangan budaya mereka'. Pendukung FPIC adalah UNDRIP, Konvensi Kean ekaragaman Hayati dan Konvensi Organisasi Perburuhan Internasional, yang merupakan instrumen internasional paling kuat dan komprehensif yang mengakui kesengsaraan Penduduk Asli dan mempertahankan hak-hak mereka. Food and Agriculture Organization of United Nation, Free Prior and Informed Consent - An Indigenous Peoples' right and a good practice for local communities, Food and Agriculture Organization of United Nation, https://www.un.org/development/desa/ 
telah diperkenalkan ke dalam hukum nasional beberapa negara yang sedang berkembang untuk mencegah pembajakan sumber daya genetik. Berdasarkan cara ini, sui generis sistem dapat diterapkan untuk: (a) penciptaan varietas baru tanaman; (b) konservasi dan dorongan untuk menggalakkan kegiatan pertanian; dan (c) pencegahan penyalahgunaan sumber daya genetik tanaman.

f. Eksklusivitas atas Uji Data terkait dengan Produk Farmasi dan Kimia

Pasal 39.3 dari TRIPS menetapkan, semua pihak dari seluruh anggota harus melindungi kerahasiaan data yang diajukan untuk persetujuan pemasaran, perlindungan hukum ini relatif terbatas, karena hanya diperlukan untuk entitas kimia baru. Perlindungan harus tersedia hanya untuk melindungi terhadap "penggunaan komersial yang tidak adil" dan "pengungkapan" data. Tidak ada ketentuan TRIPS yang mengharuskan negara anggota untuk memberikan perlindungan eksklusivitas kepada orang pertama yang menyampaikan persetujuan data untuk pemasaran. ${ }^{37}$

Beberapa negara maju, termasuk AS, memberikan perlindungan TRIPS-Plus berdasarkan eksklusivitas data untuk mempertahankan keunggulan teknologi dan ekonomi perusahaan multinasionalnya. Semua FTA yang masuk ke dalam permintaan Amerika Serikat untuk perlindungan data uji yang dirahasiakan dengan mensyaratkan, mitra dagang harus memberikan hak eksklusif pada data selama 5 tahun. ${ }^{38}$

\section{Perlindungan Merek Dagang yang Tidak Jelas Visual}

Pasal 15 Perjanjian TRIPS, merek dagang adalah tanda yang digunakan oleh siapa pun dalam bisnis atau perdagangan untuk membedakan barang atau jasa dari orang lain. Merek dagang dapat berupa nama pribadi, huruf, angka, elemen figuratif, warna dan kombinasi dari semuanya. Merek dagang yang dapat didaftarkan harus berbeda (yaitu dapat membedakan barang atau layanan dari pemilik bentuk barang atau jasa lainnya).

indigenouspeoples/publications/2016/10/free-prior-and-informed-consent-an-indigenous-peoplesright-and-a-good-practice-for-local-communities-fao/, diakses pada tanggal 21 Oktober 2018.

37 Carlos María Correa, Protection of Data Submitted for the Registration of Pharmaceuticals: Implementing the Standards of the TRIPS Agreement, South Centre, Geneva, 2002.

38 Ruth Lopert and Deborah Gleeson, "The High Price of "Free" Trade: U.S. Trade Agreements and Access to Medicines", the Journal of Law, Medicine and Ethics, Vol 41, Issue 1, Spring 2013, hlm. 199-223. 
Menurut TRIPS-Plus, para pihak untuk melindungi tidak hanya menandai terkait dengan frase, kombinasi warna, dan bentuk dan elemen konfigurasi barang, tetapi juga tanda-tanda yang tidak terlihat mata. Rezim perdagangan baru ini memungkinkan orang untuk mendaftarkan merek didasarkan pada identifikasi oleh suara, tekstur dan aroma. ${ }^{39}$

\section{Perlindungan Hak Cipta Untuk Teknologi Digital}

Perjanjian TRIPS tidak memasukkan standar minimum tentang isu-isu HKI tertentu di dunia maya. Namun, pada tahun 1996 World Intellectual Property Organisation (WIPO) telah mengadopsi dua "perjanjian internet": WIPO Copyright Treaty dan the WIPO Performances dan Phonograms Treaty. Kedua perjanjian tersebut menciptakan bentuk hukum yang sama sekali baru dalam HKI dengan memasukkan internet, dengan tujuan agenda digital WIPO dipertimbangkan oleh semua mitra dagang. Misalnya, masa perlindungan 70 tahun setelah kematian pencipta dan bukan 50 tahun seperti yang diatur dalam Pasal 9.1 TRIPS ${ }^{40}$ dan Pasal 7 (1) Konvensi Berne ${ }^{41}$, kecuali mengenai BFTA Amerika Serikat dengan Vietnam dan Jordan.

FTA melarang tindakan pengelakan teknologi untuk melindungi pekerjaan, termasuk manufaktur, impor atau distribusi perangkat untuk melakukannya. Juga, mengamanatkan pertanggungjawaban penyedia layanan internet yang mendistribusikan konten yang melanggar hak cipta melalui server dan jaringan. Kewajiban tersebut terinspirasi oleh Pasal 18 dari WIPO Performances and Phonograms Treaty dan Pasal 11 dari Perjanjian Hak Cipta WIPO, serta Undang-Undang Hak Cipta Milenium Digital Amerika Serikat tahun 1998.42

Menurut Laporan UNESCO: Hak Cipta telah muncul sebagai salah satu cara terpenting untuk mengatur arus ide dan produk berbasis pengetahuan internasional, dan menjadi instrumen utama industri pengetahuan abad $21 .{ }^{43}$ Karena, kepemilikan hak cipta sebagian besar berada di tangan negara-negara industri besar dan perusahaan multimedia utama. ${ }^{44}$ Industri berbasis hak cipta termasuk penerbitan, film, televisi, radio, musik dan

39 Pasal. 16.2 (1), United State-Singapore BFTA, United States Trade Representative, https://ustr.gov/tradeagreements/free-trade-agreements/singapore-fta/final-text, diakses pada tanggal 20 Oktober 2017.

40 Pasal 9. 1 dari TRIPS, Anggota harus mematuhi Pasal 1 hingga 21 dari Konvensi Bern (1971) dan Apendiks. Namun, anggota tidak akan memiliki hak atau kewajiban berdasarkan perjanjian ini berdasarkan Pasal 6 bis Konvensi itu atau hak yang diperoleh darinya.

41 Pasal 7 (1) Konvensi Berne, Jangka waktu perlindungan yang diberikan oleh Konvensi ini adalah umur penulis dan lima puluh tahun setelah kematiannya.

42 Art 15.4 of the US-CAFTA and Dominican Republic FTA.

43 UNESCO, World Information Report 1997/98, Paris: UNESCO, 1998, hlm. 320, http://www.unesco.org/ chap23.pdf, diakses pada tanggal 20 Oktober 2017.

44 Ibid. 
perangkat lunak komputer telah membantu meningkatkan produktivitas secara dramatis dengan membantu penciptaan produk berbasis informasi seperti perangkat lunak, surat elektronik atau database komputer ilmiah yang canggih. ${ }^{45}$

Menurut Komisi HKI Inggris, ekonomi global berbasis pengetahuan, teknologi komputer merupakan persyaratan penting untuk mengakses dan menggunakan informasi, mempercepat transfer teknologi dan mendorong pertumbuhan produktivitas. ${ }^{46}$ Hak cipta juga dapat meningkatkan biaya industri kreatif. ${ }^{47}$ Selain itu juga, banyak ketentuan BFTA AS dan mitra dagangnya mencerminkan ketentuan-ketentuan yang ada yaitu Digital Millenium Copyright Act 1998 (DMCA).

Era baru untuk HKI akan memungkinkan pemilik konten menikmati perlindungan yang lebih besar dari aturan hak cipta konvensional. Perlindungan digital akan memungkinkan pemilik untuk mengakses kondisi dari karya-karya yang oleh hukum hak cipta secara tegas tidak dilindungi lagi untuk merangsang kreativitas lebih lanjut (yaitu karya-karya yang telah jatuh ke dalam domain publik). Ruang lingkup penggunaan online secara adil akan dipersempit, sebagai pemilik konten dapat meminta pembayaran atas penggunaan atau excerpting sebuah karya digital, terlepas dari tujuan pengguna. ${ }^{48}$

Situasi terburuk muncul, ketika klausul reproduksi sementara dimasukkan ke dalam hukum nasional. Bandingkan dengan aturan hak cipta konvensional bahwa tidak ada kontrol diberikan kepada pemilik hak, larangan reproduksi sementara akan memungkinkan pemilik hak cipta untuk mengontrol penggunaan internet. Karena, setiap penggunaan internet browser, yang memerlukan penyimpanan beberapa detik dalam RAM, akan merupakan menyalin. Sedangkan penggunaan karya cipta konvensional, seperti membaca buku, bukan pelanggaran hak cipta, browsing atau menggunakan internet akan dilarang atas dasar pelanggaran hak cipta.

\section{KESIMPULAN}

Filosofi ketentuan TRIPS-Plus dalam perjanjian perdagangan bebas bilateral adalah untuk menerapkan tentang perlindungan dan penegakan HKI yang lebih luas daripada yang telah

45 Report of the Commission on Intellectual Property Rights, Integrating Intellectual Property Rights and Development Policy, London: Commission on Intellectual Property Rights, 2002, hlm. 95.

46 Ibid. hlm. 100 dan 104.

47 Michelle Boldrin \& David K. Levine, Against Intellectual Monopoly, New York: Cambridge University Press, 2007, hlm. 107.

48 Julie E. Cohen, “Lochner in Cyberspace: The New Economic Orthodoxy of "Right Management"”, 97 Mich. L. Rev. 462, 1998. 
ditetapkan dalam perjanjian multilateral, yaitu: (1) Konvensi Paris (2) Konvensi Bern (3) Perjanjian TRIPS WTO. Sehingga ketentuan-ketentuan tersebut menghapuskan standar minimum dan fleksibilitas yang disediakan dalam Perjanjian TRIPS. Hal tersebut mengakibatkan: Pertama, adanya pembatasan alasan untuk pengecualian dari sesuatu/invensi yang bisa di patenkan. Sehingga semua invensi bisa dipatenkan tanpa pengecualian, meskipun itu invensi yang terkait dengan tanaman, hewan, proses biologis, gen, rentetan gen, metode bisnis dan program komputer. Kedua, adanya pembatasan pada pemberian lisensi wajib. Sehingga dapat meningkatkan harga obat-obatan baru dan membuat pengobatan menjadi tidak mudah diakses karena "lisensi wajib". Ketiga, adanya pembatasan ruang lingkup exhaustion of rights dan impor paralel. Sehingga hal ini memiliki dampak khusus pada produk farmasi, di mana harga untuk produk yang sama sangat bervariasi di antara negara-negara yang berbeda, karena pemegang HKI asli akan terus melakukan kontrol atas penjualan, transfer atau penggunaan obat atau jasa setelah penjualan pertama. Keempat, adanya perpanjangan jangka waktu perlindungan paten. Sehingga ada penundaan yang tidak rasional dalam pemberian paten. Kelima, adanya kewajiban perlindungan paten untuk perlindungan varietas tanaman. Sehingga meniadakan hak petani yang diadopsi oleh Organisasi Pangan dan Pertanian (FAO) yang bertujuan memberikan penghargaan kepada petani yang telah melestarikan sumber daya genetik tanaman dan pengembangan varietas tanaman. Keenam, adanya hak eksklusivitas atas uji data sehubungan dengan produk farmasi dan kimia. Sehingga menghasilkan efek negatif karena mengurangi kompetisi di sektor swasta dan akan membatasi akses produk produsen obat generik. Ketujuh, adanya perluasan merek dagang yang meliputi tidak hanya sesuatu yang visual, tetapi juga didasarkan pada identifikasi oleh suara, tekstur dan aroma. Kedelapan, adanya perlindungan hak cipta yang mewajibkan negara-negara penandatanganan untuk mengadopsi perjanjian WIPO Copyright Treaty dan the WIPO Performances and Phonograms Treaty. Sehingga menghambat pertumbuhan dan perkembangan industri berbasis pengetahuan.

Oleh karena itu, pemerintah Indonesia sudah seharusnya bersikap tegas dan berani untuk melakukan perlawanan dan penolakan terhadap perjanjian-perjanjian bilateral di bidang perdagangan investasi dengan negara-negara lain yang mensyaratkan perlindungan HKI yang lebih tinggi dari pada standar minimum yang telah ditetapkan dalam TRIPS. Selanjutnya pemerintah Indonesia juga seharusnya berani mengambil sikap untuk mengevaluasi dan membatalkan perjanjian-perjanjian perdagangan bilateral yang 
mengaitkan perlindungan HKI dengan standar tinggi atau TRIPS-Plus sebagai bagian dari kesepakatan, seperti perjanjian BFTA Indonesia-Jepang yang mana salah satu bab perjanjiannya mengandung perlindungan HKI berstandar tinggi (TRIPS-Plus). Lebih lanjut, pemerintah harus memperhatikan ketentuan-ketentuan HKI nasional yang mengandung standar tinggi (TRIPS-Plus) untuk segera direvisi dan diganti dengan ketentuan-ketentuan yang sesuai dengan ketentuan perjanjian TRIPS.

\section{Daftar Pustaka}

\section{Buku}

Abbott, Frederick M. Intellectual Property Provisions of Bilateral and Regional Trade, Geneva: UNCTAD - ICTSD Project on IPRs and Sustainable Development, 2006.

Barizah, Nurul, Intellectual Property Implications on Biological Resources: Indonesia's Adoption of International Intellectual Property Regimes and the Failure to Adequately Address the Policy Challenges In the Area of Biological Resources, Jakarta: The Nagara Institute, 2010.

Boldrin, Michelle \& David K. Levine, Against Intellectual Monopoly, New York: Cambridge University Press, 2007.

Carvalho, Nuno Pires de, The TRIPS Regime of Patent Right, 2nd Edition, The Netherlands: Kluwer Law International, 2005.

Chu, Yi-Jen. The Evolution of US and EU Approaches to Intellectual Property Provisions Related to Public Health in Free Trade Agreements: Are They Responding to Public Health Concerns?, Munich Intellectual Property Law Center (MIPLC) Master Thesis (09/10) No. 5.

Commission on Intellectual Property Rights, Integrating Intellectual Property Rights and

Development Policy. London: Commission on Intellectual Property Rights, 2002.

Correa, Carlos M, Integrating Public Health Concerns Into Patent Legislation in Developing Countries, Geneva: South Centre, 2000.

, Protection of Data Submitted for the Registration of Pharmaceuticals: Implementing the Standards of the TRIPS Agreement, Geneva: South Centre, 2002. , Research Handbook on the Protection of Intellectual Property under WTO Rules Intellectual Property in the WTO Volume I, Cheltenham, UK: Edward Elgar, 2010.

Heath, Christopher and Anselm Kamperman Sanders (ed), Intellectual Property and Free Trade Agreements, Oregon: Oxford and Portland, 2007. 
Marzuki, Peter Mahmud, Penelitian Hukum, Cetakan ke 6, Jakarta: Kencana Prenada Media Group, 2010.

Mayne, Ruth, Regionalism, Bilateralism, and "TRIPS Plus" Agreements: The Threat to Developing Countries, UNDP Human Development Report Office Occasional Paper, 2005.

Mohamadieh, Kinda et.al., The Arab Region and Trade Liberalization Policies A Look Into Sectoral Implications, Beirut, Lebanon: The Arab NGO Network For Development (ANND), 2011.

Musungu, Sisule F and Graham Dutfield, Multilateral Agreements and a TRIPS-Plus World: The World Intellectual Property Organisation (WIPO), Geneva and Ottawa: Quaker United Nations Office (QUNO), Quaker International Affairs Programme (QIAP), 2003. Purba, Achmad Zen Umar, Perjanjian TRIPS dan Beberapa Isu Strategis, Bandung: Kerja Sama Badan Penerbit FH Universitas Indonesia Jakarta dan Penerbit Alumni, 2011. Report of the Commission on Intellectual Property Rights, Integrating Intellectual Property Rights and Development Policy, London: Commission on Intellectual Property Rights, 2002.

Roffe, Pedro, Bilateral agreements and a TRIPS-Plus world: the Chile-USA Free Trade Agreement, Quaker International Affairs Programme, Ottawa, 2004.

Vivas-Eugui, David, Regional and bilateral agreements and a TRIPS-Plus world: the Free Trade Area of the Americas (FTAA), Geneva and Ottawa: Quaker United Nations Office (QUNO), Quaker International Affairs Programme (QIAP), International Centre for Trade and Sustainable Development (ICTSD), 2003.

\section{Jurnal}

Barizah, Nurul, “TRIPS-Plus Provisions on Patent under Indonesia's Bilateral Free Trade Agreement”, Jurnal Hukum Ius Quia Iustum, Vol 21, No. 3, 2014.

Cohen, Julie E, "Lochner in Cyberspace: The New Economic Orthodoxy of "Right Management”, 97 Mich. L. Rev. 462, 1998.

Lopert, Ruth and Deborah Gleeson, "The High Price of "Free" Trade: U.S. Trade Agreements and Access to Medicines", the Journal of Law, Medicine and Ethics, Vol 41, Issue 1, Spring 2013.

Mercurio, Bryan. "TRIPS, Patents, and Access to Life Saving Drugs in the Developing World", 8 Marq. Intell. Prop. L. Rev. 211, 1, 2004. 
Xiong, Ping, "TRIPS-Plus Provisions And The Approaches To Interpretation Of Free Trade Agreements And TRIPS: Do They Affect Public Health?", Journal of World Trade, Vol. 46, No. 1, 2012.

\section{Internet}

Agarwa, Sunil Kumar, TRIPS-plus Agenda Through Anti-counterfeiting Trade Agreement: Implication For India, Social Science Research Network, tersedia di SSRN: http://ssrn.com/abstract=1868026 or http://dx.doi.org/10.2139/ssrn.1868026, hlm. 2, diakses pada tanggal 21 September 2017.

Dutfield, Graham, "To Copy Is To Steal": TRIPS, (Un)Free Trade Agreements and The New Intellectual Property Fundamentalism, 2006 (1) The Journal of Information and Technology Law (JILT), http://go.warwick.ac.uk/jilt/2006_1/dutfield/, diakses pada tanggal 26 Juli 2016.

Food and Agriculture Organization of United Nation, Free Prior and Informed Consent - An Indigenous Peoples' Right And a Good Practice For Local Communities, https://www.un.org/development/desa/indigenouspeoples/publications/2016/ 10/free-prior-and-informed-consent-an-indigenous-peoples-right-and-a-goodpractice-for-local-communities-fao/, diakses pada tanggal 21 Oktober 2018.

UNESCO, World Information Report 1997/98, Paris: UNESCO, 1998, http://www.unesco.org/webworld/com_inf_reports/wirenglish/chap23.pdf, diakses pada tanggal 20 Oktober 2017.

United States Trade Representative, United State-Singapore BFTA, United States Trade Representative, https://ustr.gov/trade-agreements/free-trade-agreements/ singapore-fta/final-text, diakses pada tanggal 20 Oktober 2017.

World Trade Organization, What Are Intellectual Property Rights?, World Trade Organization, https://www.wto.org/english/tratop_e/TRIPS_e/TRIPS_e.htm \#WhatAre. diakses pada tanggal 28 Agustus 2017. 